\title{
Development and Implementation of Clinical Outcome Measures for Automated Collection Within Specialty Pharmacy Practice
}

\author{
Katherine Patel, PharmD, AAHIVP; Yee-Ling Chim, PharmD; Jonathan Grant, PharmD, BCACP; \\ Molly Wascher, PharmD, MBA, BCPS; Amy Nathanson, PharmD, BCACP; \\ and Scott Canfield, PharmD, CSP
}

\begin{abstract}
BACKGROUND: Johns Hopkins Specialty Pharmacy Services recognized the need to identify and develop standardized collection methods for clinical outcome measures (COMs) to demonstrate program quality and value to third-party payers, manufacturers, and internal stakeholders.
\end{abstract}

OBJECTIVE: To define specialty COMs and develop a framework for standardized data collection and reporting.

METHODS: COMs for specialty pharmacy disease states (cystic fibrosis; hepatitis C; inflammatory conditions in dermatology, gastroenterology and rheumatology; and multiple sclerosis) were identified through a literature search, collaboration with specialty pharmacists, and committee review. Once identified, these measures were distributed to internal and external stakeholders that included specialty clinic team members, drug manufacturers, and third-party payers for input and validation. A standardized process for discrete documentation and data collection of these measures was implemented using case management software, electronic medical record integration, and informatics support.

RESULTS: 28 COMs were identified. The various data sources used to collect the COMs were incorporated into an automated virtual dashboard to allow for regular review and sharing with clinicians, leadership, and other key stakeholders. The virtual dashboard included COMs with data derived from electronic medical records $(n=9)$, patient-reported outcomes based on responses to pharmacist-delivered questions $(n=11)$, and pharmacist assessment of outcomes $(n=8)$. The completed virtual dashboard was further refined to allow for reporting of both population and patient-level outcome results on a quarterly basis.

CONCLUSIONS: This project describes methods to standardize documentation, data collection, and reporting of clinical outcomes data for multiple specialty conditions in a health system-integrated specialty pharmacy program. Through literature review and stakeholder consultation, a variety of potential COMs were identified for further evaluation of feasibility and value considering documentation and data collection requirements. Incorporation of COMs into a virtual dashboard will help facilitate the evaluation of program effectiveness, quality improvement planning, and sharing with stakeholders. Additional opportunities exist to further standardize COMs across the pharmacy industry to allow for future benchmarking and standardized evaluation of patient care programs.

J Manag Care Spec Pharm. 2020;26(7):901-09

Copyright @ 2020, Academy of Managed Care Pharmacy. All rights reserved.

\section{What is already known about this subject}

Specialty pharmacy continues to grow and gain attention from stakeholders that require and value the reporting of quality and performance measures.

Because of increasing pressure on pharmacies caused by restricted manufacturers and payer networks, specialty pharmacies need to continuously identify and effectively manage their highest cost and highest risk patients to remain competitive.

Few real-world clinical outcome measures (COMs) have been proposed for consideration by specialty pharmacies, and there is limited literature on how specialty pharmacies can collect and report meaningful outcomes data beyond adherence rates using standardized methodology.

\section{What this study adds}

This report defines a process to identify, assess, validate, and implement appropriate and desirable COMs for specialty conditions in a health system-integrated specialty pharmacy program. This report provides examples of obtainable and meaningful COMs that specialty pharmacy programs should consider reporting and evaluating for patients receiving treatment for cystic fibrosis; hepatitis C; inflammatory conditions in dermatology, gastroenterology, and rheumatology; and multiple sclerosis.

The construction and use of a virtual dashboard to automate and display COMs is highlighted and may be used for program quality improvement planning, identification of high-risk patients, and sharing of information with key stakeholders.

$\mathrm{T}$ he National Association of Specialty Pharmacy defines specialty drugs as complex medications used to treat serious and potentially life-threatening conditions including cancer, hepatitis $C$, rheumatoid arthritis, human immunodeficiency virus, multiple sclerosis, and more. These medications are typically high cost and require special handling and intensive patient management. Specialty pharmacy is a unique and growing industry that continues to gain attention, and many health systems are developing specialty pharmacy programs to match the needs of a rapidly growing patient population. ${ }^{1}$

The specialty pharmacy market is shifting, with a larger proportion of specialty pharmacies owned by health systems, 
accounting for $27 \%$ of accredited specialty pharmacies in 2018 compared with $16 \%$ in $2015 .^{2}$ In 2018 , the use of specialty medications grew by more than twice the rate since 2017 as compared to nonspecialty medications. ${ }^{3}$ The American Society of Health-System Pharmacist's 2016-2020 Pharmacy Forecast suggests that use of high-cost specialty medications to treat nonmalignant autoimmune and rare disorders will increase by $50 \%$ over the next 5 years. ${ }^{4}$ This growth will be compounded by the expectation that new biologic and specialty products will replace at least $25 \%$ of chronic care medications for the treatment of common disorders. ${ }^{4}$ The Express Scripts 2019 Drug Trend Report shows that, although specialty medications are used by only $2 \%$ of patients on its plans, almost half (47.7\%) of the organization's total drug spending was on specialty drugs. ${ }^{5}$

Health system specialty pharmacies aim to provide a seamless and integrated care model between the provider, pharmacist, and patient and to provide personalized patient care that improves medication access and adherence. Johns Hopkins Home Care Group (JHHCG) Specialty Pharmacy Services provides comprehensive patient care with a focus on patients seen by prescribers within the Johns Hopkins Health System. The clinical care model includes a combination of clinic-embedded pharmacists and centralized pharmacy team members providing telephonic or virtual patient support, as well as multiple locations that provide product dispensing for prescription pickup or home delivery. This model includes services for financial navigation, patient education, longitudinal monitoring, and adherence support. A variety of disease-specific patient management programs are provided, including services for chronic hepatitis $\mathrm{C}$ infection, rheumatoid arthritis, inflammatory bowel disease, multiple sclerosis, cystic fibrosis, and other rare or high-risk conditions. JHHCG Specialty Pharmacy Services have specialty pharmacy accreditation from URAC.

Health systems may enhance the patient experience and optimize outcomes by integrating specialty pharmacy services; however, increasing pressure from restricted drug distribution and payer networks can present challenges. Restricted specialty pharmacy networks are a common component of cost containment strategies used by manufacturers or payers. Additional considerations for restricting a specialty pharmacy network may include a desire for expertise in specific disease states, ability to demonstrate improved service quality, or requirements for product handling and oversight. Limited networks restrict patient choice and, when encountered, present challenges for health systems looking to provide comprehensive services for their patients within an integrated care model. Because of continued market consolidation and vertical integration between insurance companies, pharmacy benefit managers, and large specialty pharmacies, health system specialty pharmacies face increased challenges in gaining access to or remaining in restricted networks. To combat losing their ability to provide comprehensive pharmacy services for their patients, it is important for health system specialty pharmacies to secure and maintain contracts with third-party payers and specialty manufacturers. Inclusion in such contracts may depend on a pharmacy's ability to positively differentiate itself and demonstrate measurable improvements in patient care. ${ }^{6,7}$ Using data that demonstrate the effect of pharmacy services on clinical outcomes is one avenue that can be used to facilitate discussions and relationships with payers and manufacturers.

The challenge in obtaining and reporting this data is that few real-world clinical outcome measures (COMs) exist for diseases managed by specialty pharmacies, and there is limited literature related to specialty pharmacy data collection and outcome reporting. A limited number of COMs relevant to specialty pharmacy have been proposed, most within the disease categories of hepatitis $\mathrm{C}$, multiple sclerosis, and inflammatory bowel disease..$^{8-11}$ Because of a lack of established COMs, specialty pharmacies often rely on specialty pharmacy accreditation, operational metrics, or satisfaction survey data to demonstrate their ability to deliver services that meet performance and customer satisfaction standards. ${ }^{12}$

Multiple specialty pharmacy accrediting bodies exist, including URAC, Accreditation Commission for Health Care, and The Center for Pharmacy Practice Accreditation. Accreditation compliance requires continual demonstration of performance improvement in quality and patient care and is often required for consideration in third-party payer and manufacturer restricted networks. ${ }^{13}$ Maintaining accreditation is key as payers continue to challenge specialty pharmacy networks to prove their value. ${ }^{14}$

Despite the value that accreditation provides, accreditation standards are typically nonspecific when it comes to COMs and instead focus on operational quality (e.g., call abandonment rates and dispensing errors) and the presence of standard service offerings (e.g., clinical management programs and prior authorization services) with limited emphasis on COMs, with the exception of surrogate markers such as adherence rates (e.g., proportion of days covered and therapy persistence). While the measures defined by accreditation organizations demonstrate some aspects of the quality of services offered, the reporting of additional COMs may enhance or better demonstrate the effect and value of these services on patient care.

As a result, specialty pharmacies should consider the benefits of reporting clinical data and take the responsibility of determining appropriate COMs for the conditions covered by their specialty services. In order to demonstrate the value of services and improve stakeholder engagement, specialty pharmacies need to identify these COMs, eliminate process variations, and create an efficient system for data collection, tracking, and reporting of clinical outcomes data. ${ }^{15}$ 


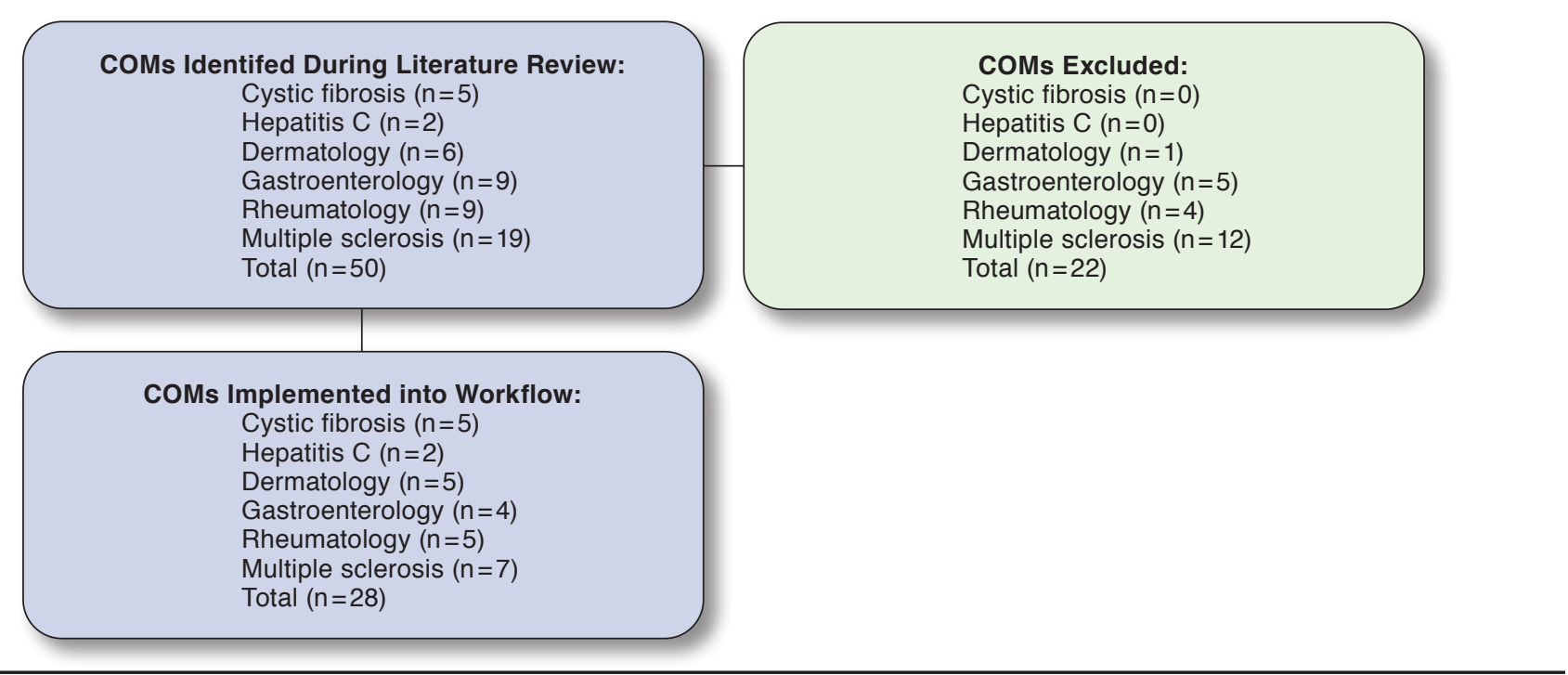

COMs=clinical outcome measures.

\section{Methods}

Four specialty conditions were selected for identifying, validating, implementing, and reporting COMs: cystic fibrosis; hepatitis C; inflammatory conditions in dermatology, gastroenterology and rheumatology; and multiple sclerosis. A literature review was conducted to identify meaningful COMs that could be collected and reported to demonstrate patient disease activity and perceived quality of life (Figure 1). A review of disease-specific guidelines and clinical trials provided a list of outcomes for exploration as COMs. These outcomes and respective measures were assessed with the aid of published clinical outcome assessments that analyzed the reliability, validity, attainability, and responsiveness of these COMs in real-world practice. ${ }^{16}$ This process resulted in a list of potential COMs, including measures related to physical assessments, lab results, and questionnaires. This list was reviewed and approved for implementation by a project committee consisting of specialty pharmacy managers and clinical pharmacists with expertise in specialty conditions and workflow.

Identified COMs were reviewed for appropriateness, quality, and feasibility of implementation. This evaluation included assessment of current documentation methods and consideration of the effect of documentation requirements on pharmacy workflow and sustainability of data collection through automation. The documentation and data sources included the pharmacy-dispensing system, case management software, and electronic medical records (EMR).

Following initial identification of COMs and data sources, measures were validated through consultation with additional internal and external stakeholders. This process was facilitated through stakeholder review of documents that included information on the selected COMs, such as measure name, data source, measure description, and measure calculation. Internal stakeholders included Johns Hopkins specialty clinic providers and additional Johns Hopkins specialty pharmacists. External stakeholders included specialty drug manufacturers and thirdparty payers. Stakeholders were requested to provide feedback on the proposed COMs, including level of value, measure and method appropriateness, and feasibility. Stakeholders were prompted to provide any additional measures that they would like to see reported.

After validation of COMs, standardized processes for documentation and data collection were implemented. Implementation included the addition of new documentation elements and data fields within case management software and consultation with internal pharmacy informatics experts to collect, organize, and consolidate data from multiple sources into 1 virtual dashboard using a business intelligence platform. Patient identifiers such as name, date of birth, and medical record numbers were used to ensure that patient information across multiple data sources was evident. To incorporate COMs into an automated dashboard, questions and EMR data needed to be precisely defined with discrete and quantifiable results. This required collaboration and discussion with informatics personnel regarding methods to categorize, organize, measure, and report COM data. Once a virtual dashboard was constructed, data validation was performed to confirm data quality and accuracy. 


\section{Results}

A total of 28 COMs was identified and implemented for data collection (Table 1). Many of the COMs included were adapted from measures identified during the literature review to allow for feasible integration into workflow with consideration of resources, data availability, and time burden..$^{8,9,16-22}$ Adjustments to documentation and data collection methods were implemented into pharmacy workflow. Considering the data sources available, 3 categories of COMs were defined: automated EMR outcomes (EMR, $\mathrm{n}=9$ ), patient-reported outcomes (PRO, $\mathrm{n}=11$ ), and pharmacist-assessment outcomes (PAO, $\mathrm{n}=8)$.

EMR outcomes were defined as COMs pulled directly and automatically from medical records, such as lab values or physician assessments represented as discrete data elements. PROs were defined as COMs with results found within the case management software where pharmacists have documented patient responses to disease activity or quality of life questions as part of telephonic or in-person clinical follow-up assessments. PAOs were defined as COMs where pharmacists have documented outcome results within the case management software based on a review of patient medical records that included physician assessments, lab values, and medication records. In some instances, the collection of PAOs was also supplemented by the pharmacist confirming the information with the patient during a telephone call or clinic visit.

In total, 7 COMs were identified for multiple sclerosis (5 EMR, $1 \mathrm{PRO}$, and $1 \mathrm{PAO}$ ). Five COMs were identified for each of the following: cystic fibrosis (2 EMR, 2 PRO, 1 PAO), dermatology (2 PRO and $3 \mathrm{PAO}$ ), and rheumatology (2 EMR and $3 \mathrm{PRO}$ ). Four COMs were identified for gastroenterology (3 PRO and $1 \mathrm{PAO}$ ) and 2 COMs for hepatitis C (2 PAO).

The virtual dashboard was piloted to confirm the ability to automatically calculate and present COM data using descriptive statistics. Data for each COM were designed to be reported on a quarterly basis and to include only patients who had a pharmacist-documented assessment for the selected disease state within each quarter. COM data included either a patient's most recent values (e.g., lab value) or a sum of values for each COM during this time (e.g., number of total hospital admissions during the quarter). COM data were summarized for both population- and patient-specific measures, including a display of trends over time. Population data were presented as the percentage of the population meeting certain criteria as defined in Table 1.

\section{Discussion}

Literature that defines and uses standardized COMs within specialty pharmacy is limited. Identifying and tracking these outcomes could present a significant opportunity for health systems to differentiate their services and effect on patient care. Overall, specialty pharmacies have minimal guidance as to how to collect and report clinical outcomes data for their patients. As a result, a majority of measure reporting in specialty pharmacy focuses on operational quality and performance measures as opposed to the effect of performance on clinical outcomes.

A high degree of interest in further defining, collecting, and reviewing specialty clinical outcomes data was discovered through internal and external stakeholder feedback received during measure validation. Many of the initially identified COMs included physician-performed or in-person clinical assessments (e.g., MRI scan results), lengthy quality of life questionnaires (e.g., short inflammatory bowel disease questionnaire), or processes that required close follow-up that only exist in the structured environment of a formal study. Although all measures could not be implemented into documentation and data collection processes due to issues with feasibility, feedback and suggestions received were valuable in determining which COMs were most desirable.

The challenge in identifying and implementing COMs is often in translating potential outcomes into measures that are discrete, quantifiable, allow for automatic data collection, and present minimal barriers to collection by pharmacy team members. As a result, many of the COMs considered during this evaluation required modification for integration within specialty pharmacy workflow. Contribution from pharmacy informatics experts was crucial to consolidate data from multiple sources and compile results into a single virtual dashboard. The virtual dashboard can be used to create benchmarks for program assessment, assist in designing targeted interventions, and identify high-risk patients that may benefit from more intensive monitoring.

Considering implementation and data collection, EMR COMs require the least amount of labor from the specialty pharmacy because they are directly pulled from existing medical records and do not require pharmacist intervention. The primary drawback of EMR-identified COMs is that some may be obtained less frequently, since patients may be assessed more frequently by a pharmacist than seen in clinic or have completed labs. This represents a barrier for PAOs as well, with some values being gathered from physician-assessment notes that occur less frequently than pharmacist assessments. PROs represent the most complete data, considering that patients are required to have a pharmacist assessment to be included. PROs also require the most labor from pharmacists because of the time required to perform assessments and collect data. Results for PROs may be subject to more inaccuracy, however, considering the subjective nature of the responses.

\section{Limitations}

This study has some limitations, including the limited number of specialty conditions selected, COM data sources that may provide incomplete data, and limitations of replicability for pharmacies with limited access to patient medical records. 


\section{TABLE 1 Clinical Outcome Measures}

\begin{tabular}{|c|c|c|c|}
\hline $\begin{array}{l}\text { Clinical Outcome } \\
\text { Measure }\end{array}$ & Data Source & Description & Measure Calculation \\
\hline \multicolumn{4}{|l|}{ Cystic Fibrosis } \\
\hline BMI & EMR & $\begin{array}{l}\text { Measure of nutritional status from EMR encounter within } \\
\text { the same quarter as pharmacist assessment }\end{array}$ & $\begin{array}{l}\text { Adults: \% of patients with: } \\
\text { - Low }\left(<22 \mathrm{~kg} / \mathrm{m}^{2}\right) \\
\text { - At goal }\left(\geq 22 \mathrm{~kg} / \mathrm{m}^{2}\right) \\
\text { Pediatrics: Average Population BMI }\end{array}$ \\
\hline FEV1 & EMR & $\begin{array}{l}\text { Measure of lung function and disease activity from } \\
\text { EMR encounter within the same quarter as pharmacist } \\
\text { assessment }\end{array}$ & $\begin{array}{l}\text { \% of patients with: } \\
\text { - }<25 \% \text { of expected value } \\
\text { - } 25 \%-50 \% \text { of expected value } \\
\text { - } 50 \%-75 \% \text { of expected value } \\
\text { - } 75 \%-100 \% \text { of expected value } \\
\text { - }>100 \% \text { of expected value }\end{array}$ \\
\hline Disease burden & PRO & $\begin{array}{l}\text { Patient response: "To what extent have you had trouble } \\
\text { keeping up with your schoolwork, professional work, or } \\
\text { other daily activities during the past two weeks?" }\end{array}$ & $\begin{array}{l}\text { \% of patients who responded: } \\
\text { - You have had no trouble keeping up } \\
\text { - You have managed to keep up, but it's been difficult } \\
\text { - You have been behind } \\
\text { - You have not been able to do these activities at all }\end{array}$ \\
\hline $\begin{array}{l}\text { Treatment } \\
\text { burden }\end{array}$ & PRO & $\begin{array}{l}\text { Patient response: "To what extent do your treatments } \\
\text { make your daily life more difficult?" }\end{array}$ & $\begin{array}{l}\text { \% of patients who responded: } \\
\text { - Not at all } \\
\text { - A little } \\
\text { - Moderately } \\
\text { - A lot }\end{array}$ \\
\hline $\begin{array}{l}\text { Pulmonary } \\
\text { exacerbations }\end{array}$ & $\mathrm{PAO}$ & $\begin{array}{l}\text { Pharmacist assessment of EMR and patient response: } \\
\text { "How many exacerbations has the patient experienced } \\
\text { since their last assessment?" }\end{array}$ & $\begin{array}{l}\text { \% of patients with: } \\
\text { - } 0 \text { exacerbations } \\
\text { - } 1 \text { exacerbation } \\
\text { - } 2 \text { exacerbations } \\
\text { - } \geq 3 \text { exacerbations }\end{array}$ \\
\hline \multicolumn{4}{|l|}{ Hepatitis C } \\
\hline $\begin{array}{l}\text { Completion/ } \\
\text { abandonment } \\
\text { rate }\end{array}$ & $\mathrm{PAO}$ & $\begin{array}{l}\text { Pharmacist assessment of EMR and patient's reason for } \\
\text { discontinuation of HCV therapy }\end{array}$ & $\begin{array}{l}\text { \% of patients: } \\
\text { - Completing full course of therapy } \\
\text { - Did not complete full course (reason) } \\
\text { o Financial hardship } \\
\text { o Nonadherence } \\
\text { o Side-effect intolerance } \\
\text { o Drug on hold } \\
\text { o Unable to reach patient } \\
\text { o Patient deceased } \\
\text { o Change of therapy } \\
\text { o Drug obtained from other source } \\
\text { o Change of pharmacy }\end{array}$ \\
\hline SVR12 & $\mathrm{PAO}$ & $\begin{array}{l}\text { Measure of successful treatment of HCV as indicted by } \\
\text { HCV viral load at } 12 \text { weeks or more after HCV treatment } \\
\text { determined by pharmacist assessment of EMR }\end{array}$ & $\begin{array}{l}\text { \% of patients at } 12 \text { weeks posttreatment with: } \\
\text { - Undetectable viral load } \\
\text { - Detectable viral load }\end{array}$ \\
\hline \multicolumn{4}{|c|}{ Inflammatory Conditions - Dermatology } \\
\hline Disease burden & PRO & $\begin{array}{l}\text { Patient response: "Over the last month, how much has } \\
\text { your skin affected your ability to work/socialize?" }\end{array}$ & $\begin{array}{l}\text { \% of patients who responded: } \\
\text { - Not at all } \\
\text { - A little } \\
\text { - Moderately } \\
\text { - A lot }\end{array}$ \\
\hline $\begin{array}{l}\text { Disease } \\
\text { progression }\end{array}$ & PRO & $\begin{array}{l}\text { Patient response: "Since we last spoke, has the coverage } \\
\text { area of your plaques stayed the same, improved, or gotten } \\
\text { worse?" }\end{array}$ & $\begin{array}{l}\text { \% of patients who responded: } \\
\text { - Improved } \\
\text { - Stayed the same } \\
\text { - Worsened } \\
\text { - Unknown }\end{array}$ \\
\hline BSA & $\mathrm{PAO}$ & $\begin{array}{l}\text { Measure of percentage of body surface area affected by } \\
\text { psoriasis as documented in patient encounters }\end{array}$ & $\begin{array}{l}\text { \% of patients with: } \\
\text { - Mild psoriasis (BSA<5\%) } \\
\text { - Moderate psoriasis (BSA 5\%-10\%) } \\
\text { - Severe psoriasis (BSA>10\%) }\end{array}$ \\
\hline
\end{tabular}




\section{TABLE 1 Clinical Outcome Measures (continued)}

\begin{tabular}{|c|c|c|c|}
\hline $\begin{array}{l}\text { Clinical Outcome } \\
\text { Measure }\end{array}$ & Data Source & Description & Measure Calculation \\
\hline \multicolumn{4}{|c|}{ Inflammatory Conditions - Dermatology } \\
\hline PASI & $\mathrm{PAO}$ & $\begin{array}{l}\text { Measure of psoriasis disease activity that assesses severity } \\
\text { of lesions and area affected as documented in patient } \\
\text { encounters }\end{array}$ & $\begin{array}{l}\text { \% of patients with: } \\
\text { - Mild psoriasis }(\mathrm{PASI} \leq 5) \\
\text { - Moderate psoriasis }(5<\mathrm{PASI} \leq 12) \\
\text { - Severe psoriasis }(12<\mathrm{PASI} \leq 20) \\
\text { - Very severe psoriasis }(\mathrm{PASI}>20)\end{array}$ \\
\hline PGA & $\mathrm{PAO}$ & $\begin{array}{l}\text { Measure of psoriasis disease activity that assesses severity } \\
\text { of lesions and area affected as documented in patient } \\
\text { encounters }\end{array}$ & $\begin{array}{l}\text { \% of patients with: } \\
\text { - Clear or almost clear disease activity (PGA =0 or } 1) \\
\text { - Ongoing active disease }(P G A>1)\end{array}$ \\
\hline \multicolumn{4}{|c|}{ Inflammatory Conditions - Gastroenterology } \\
\hline Disease burden & PRO & $\begin{array}{l}\text { Patient response: "Since we last spoke, have you missed } \\
\text { days from work or school due to IBD-related symptoms?" } \\
\text { and "if yes, how many days?" }\end{array}$ & $\begin{array}{l}\text { \% of patients who responded: } \\
\text { - Yes } \\
\text { - No } \\
\text { - Unknown } \\
\text { Of patients answering yes, \% who responded: } \\
\text { - } 1-3 \text { missed days } \\
\text { - 4-6 missed days } \\
\text { - } 7-10 \text { missed days } \\
\text { - > } 10 \text { missed days }\end{array}$ \\
\hline Pain & PRO & $\begin{array}{l}\text { Patient response: "On a scale of } 0 \text { to } 10 \text {, how much pain } \\
\text { have you had because of your condition over the past } 2 \\
\text { weeks (with } 10 \text { being the worst pain imaginable and } 0 \\
\text { being no pain at all)?" }\end{array}$ & $\begin{array}{l}\text { \% of patients who responded: } \\
\text { - No pain }(0) \\
\text { - Mild pain (1-3) } \\
\text { - Moderate pain (4-6) } \\
\text { - Severe pain (7-10) }\end{array}$ \\
\hline Disease activity & PRO & $\begin{array}{l}\text { Patient response: "Since we last spoke, how would you } \\
\text { describe your disease/symptom activity?" }\end{array}$ & $\begin{array}{l}\text { \% of patients who responded: } \\
\text { - Remission } \\
\text { - Rarely active } \\
\text { - Occasionally active } \\
\text { - Sometimes active } \\
\text { - Often active } \\
\text { - Constantly active }\end{array}$ \\
\hline Hospitalizations & $\mathrm{PAO}$ & $\begin{array}{l}\text { Pharmacist assessment of EMR and patient response: } \\
\text { "Since we last spoke, have you been hospitalized due to } \\
\text { IBD-related symptoms?" and "if yes, how many times?" }\end{array}$ & $\begin{array}{l}\text { \% of patients who responded: } \\
\text { - Yes } \\
\text { - No } \\
\text { - Unknown } \\
\text { Of patients answering yes, \% with: } \\
\text { - } 1 \text { hospitalization } \\
\text { - } 2 \text { hospitalizations } \\
\text { - } 3 \text { hospitalizations } \\
\text { - }>3 \text { hospitalizations }\end{array}$ \\
\hline \multicolumn{4}{|c|}{ Inflammatory Conditions - Rheumatology } \\
\hline CRP & EMR & $\begin{array}{l}\text { Measure of acute phase reactant representing level of } \\
\text { inflammation based on lab value documented in EMR } \\
\text { during same quarter as pharmacist assessment }\end{array}$ & $\begin{array}{l}\text { \% of patients with: } \\
\text { - High }(>0.5 \mathrm{mg} / \mathrm{dL}) \\
\text { - WNL }(<0.5 \mathrm{mg} / \mathrm{dL})\end{array}$ \\
\hline$\overline{\text { ESR }}$ & EMR & $\begin{array}{l}\text { Measure of acute phase reactant representing level of } \\
\text { inflammation based on lab value documented in EMR } \\
\text { during same quarter as pharmacist assessment }\end{array}$ & $\begin{array}{l}\text { \% of patients with: } \\
\text { - High }(>25 \mathrm{~mm} / \mathrm{h}) \\
\text { - WNL }(4-25 \mathrm{~mm} / \mathrm{h}) \\
\text { - Low }(<4 \mathrm{~mm} / \mathrm{h})\end{array}$ \\
\hline $\begin{array}{l}\text { Morning joint } \\
\text { stiffness }\end{array}$ & PRO & $\begin{array}{l}\text { Patient response: "Over the past } 2 \text { weeks, have your joints } \\
\text { been stiff when you wake up in the morning? If yes, how } \\
\text { long did this extra stiffness last?" }\end{array}$ & $\begin{array}{l}\text { \% of patients who responded: } \\
\text { - Yes } \\
\text { - No } \\
\text { - Unknown } \\
\text { Of patients answering yes, \% who responded: } \\
\text { - No stiffness } \\
\text { - Less than } 1-3 \text { hours } \\
\text { - } 4-6 \text { hours } \\
\text { - } 7 \text { or more hours }\end{array}$ \\
\hline
\end{tabular}




\section{TABLE 1 Clinical Outcome Measures (continued)}

\begin{tabular}{|c|c|c|c|}
\hline $\begin{array}{l}\text { Clinical Outcome } \\
\text { Measure }\end{array}$ & Data Source & Description & Measure Calculation \\
\hline \multicolumn{4}{|c|}{ Inflammatory Conditions - Rheumatology } \\
\hline Disease burden & PRO & $\begin{array}{l}\text { Patient response: "Over the past } 2 \text { weeks, how much } \\
\text { difficulty have you had in doing physical activities due } \\
\text { to your condition on a scale of } 0 \text { to } 10 \text { (with } 10 \text { being } \\
\text { extreme difficulty and } 0 \text { being no difficulty)?" }\end{array}$ & $\begin{array}{l}\text { \% of patients who responded: } \\
\text { - No problems }(0) \\
\text { - Mild problems (1-4) } \\
\text { - Moderate problems }(5-6) \\
\text { - Severe problems (7-10) }\end{array}$ \\
\hline Pain & PRO & $\begin{array}{l}\text { Patient response: "Over the past } 2 \text { weeks, how much pain } \\
\text { have you had because of your condition on a scale of } 0 \text { to } \\
10 \text { (with } 10 \text { being the worst pain imaginable and } 0 \text { being } \\
\text { no pain at all)?" }\end{array}$ & $\begin{array}{l}\text { \% of patients who responded: } \\
\text { - No pain (0) } \\
\text { - Mild pain (1-3) } \\
\text { - Moderate pain (4-6) } \\
\text { - Severe pain (7-10) }\end{array}$ \\
\hline \multicolumn{4}{|l|}{ Multiple Sclerosis } \\
\hline $\begin{array}{l}\text { Upper extremity } \\
\text { function }\end{array}$ & EMR & $\begin{array}{l}\text { Neuro-QoL survey measure representing patient's ability } \\
\text { to carry out activities of daily living as it relates to fine } \\
\text { motor and self-care activities }\end{array}$ & $\begin{array}{l}\text { \% of patients with: } \\
\text { - No problems }(\text { score }>46) \\
\text { - Mild problems }(46 \geq \text { score }>36) \\
\text { - Moderate problems }(36 \geq \text { score } \geq 26) \\
\text { - Severe problems }(\text { score }<26)\end{array}$ \\
\hline $\begin{array}{l}\text { Lower extremity } \\
\text { function }\end{array}$ & EMR & $\begin{array}{l}\text { Neuro-QoL survey measure representing patient's ability } \\
\text { to carry out activities of daily living as it relates to } \\
\text { mobility }\end{array}$ & $\begin{array}{l}\text { \% of patients with: } \\
\text { - No problems }(\text { score }>50) \\
\text { - Mild problems }(50 \geq \text { score }>40) \\
\text { - Moderate problems }(40 \geq \text { score } \geq 30) \\
\text { - Severe problems }(\text { score }<30)\end{array}$ \\
\hline Sleep disturbance & EMR & $\begin{array}{l}\text { Neuro-QoL survey measure representing patient's } \\
\text { perception of sleep quality, depth, and restoration }\end{array}$ & $\begin{array}{l}\text { \% of patients with: } \\
\text { - No problems }(\text { score }<45) \\
\text { - Mild problems }(45 \leq \text { score }<60) \\
\text { - Moderate problems }(60 \leq \text { score } \leq 65) \\
\text { - Severe problems }(\text { score }>65)\end{array}$ \\
\hline Fatigue & EMR & $\begin{array}{l}\text { Neuro-QoL survey measure representing patient's } \\
\text { sensation of fatigue and impact on daily activities }\end{array}$ & $\begin{array}{l}\text { \% of patients with: } \\
\text { - No problems }(\text { score }<40) \\
\text { - Mild problems }(40 \leq \text { score }<50) \\
\text { - Moderate problems }(50 \leq \text { score } \leq 65) \\
\text { - Severe problems }(\text { score }>65)\end{array}$ \\
\hline Vitamin D level & EMR & $\begin{array}{l}\text { Measure of patient's vitamin D level (ng/mL) which has } \\
\text { been suggested to be associated with MS symptomatology }\end{array}$ & $\begin{array}{l}\text { \% of patients with: } \\
\text { - Goal vitamin D level }(\text { Vit } D>50) \\
\text { - Vitamin D level WNL }(50 \geq \text { Vit } D \geq 30) \\
\text { - Vitamin D deficiency }(\text { Vit D }<30)\end{array}$ \\
\hline Disease burden & PRO & $\begin{array}{l}\text { Patient response: "Since we last spoke, have you missed } \\
\text { days from work or school due to MS-related symptoms?" } \\
\text { "If Yes, how many days?" }\end{array}$ & $\begin{array}{l}\text { \% of patients who responded: } \\
\text { - Yes } \\
\text { - No } \\
\text { - Unknown } \\
\text { Of patients answering yes, \% who responded: } \\
\text { - } 1-3 \text { missed days } \\
\text { - } 4-5 \text { missed days } \\
\text { - } 6-10 \text { missed days } \\
\text { - >0 missed days }\end{array}$ \\
\hline Hospitalizations & $\mathrm{PAO}$ & $\begin{array}{l}\text { Pharmacist assessment of EMR and patient response: } \\
\text { "Since we last spoke, have you been hospitalized due to } \\
\text { MS-related symptoms?" "If yes, how many times?" }\end{array}$ & $\begin{array}{l}\text { \% of patients who responded: } \\
\text { - Yes } \\
\text { - No } \\
\text { - Unknown } \\
\text { Of patients answering yes, \% with: } \\
\text { - } 1 \text { hospitalization } \\
\text { - } 2 \text { hospitalizations } \\
\text { - } 3 \text { hospitalizations } \\
\text { - }>3 \text { hospitalizations } \\
\end{array}$ \\
\hline
\end{tabular}

$B M I=$ body mass index; $B S A=$ body surface area; $C R P=C$-reactive protein; $E M R=$ electronic medical record; $E S R=$ erythrocyte sedimentation rate; $F E V 1=$ forced expiratory volume in one second; IBD =irritable bowel disease; IV = intravenous; Neuro-QoL=Quality of Life in Neurological Disorders measurement system; $P A O=$ pharmacist-assessment outcome; $P A S I=$ psoriasis area and severity index; $P G A=$ physician global assessment; $P R O=$ patient-reported outcome; $S V R 12=$ sustained virologic response at 12 or more weeks after end of treatment; Vit $D=$ vitamin $D$; WNL = within normal limits. 
Although specialty pharmacy integration within a health system with EMR access allows for the collection of valuable outcomes, limitations exist for patient encounters outside of the health system, such as hospitalizations at an outside facility. For this reason, we selected to use a combination of PRO and EMR data at the pharmacy level to evaluate these measures, although a more complete picture may be most available from comprehensive payer claims data.

Because of the lack of specialty COM standardization, another limitation for all the COMs is the inability to directly benchmark against other specialty pharmacy programs or against clinical studies. This presents an opportunity to promote the adoption of standardized methods and metrics across pharmacy programs.

Finally, it is difficult to quantify the degree of impact attributable directly to pharmacy services for each COM, since many outside variables, including other health care team members, may contribute to the care of the patient and the resulting outcomes. It is also important to note that although these outcomes were identified as relevant and meaningful by stakeholders of Johns Hopkins, any COM should be validated with stakeholders relevant to an individual pharmacy or organization to ensure that all stakeholder needs are being addressed.

\section{Conclusions}

This project outlines a process to identify, standardize, and implement the reporting of clinical outcomes data for multiple conditions managed by a health system-integrated specialty pharmacy program. By defining and validating COMs that result in discrete and quantifiable data, it was possible to incorporate clinical outcomes into an automated virtual dashboard. This virtual dashboard will be used for continuous program quality evaluation, improvement planning, and engagement with stakeholders. The results of this project provide a list of potential COMs that a pharmacy might consider when evaluating their services and effectiveness of their patient management programs. Future studies should be conducted to assess the effect of specialty pharmacy involvement on these COMs, and further investigation is needed to create standardized COMs for specialty conditions not included in this study.

\section{Authors}

KATHERINE PATEL, PharmD, AAHIVP; YEE-LING CHIM, PharmD; JONATHAN GRANT, PharmD, BCACP; MOLLY WASCHER, PharmD, MBA, BCPS; AMY NATHANSON, PharmD, BCACP; and SCOTT CANFIELD, PharmD, CSP, Johns Hopkins Home Care Group, Baltimore, Maryland.

AUTHOR CORRESPONDENCE: Scott Canfield, PharmD, CSP, Assistant Director, Clinical Program Development, Johns Hopkins Home Care Group, 5901 Holabird Ave. A, Baltimore, MD 21224. Tel.: 608.381.4662; E-mail: scanfie1@jhmi.edu.

\section{DISCLOSURES}

No funding supported the writing of this article. The authors have no relevant conflicts of interest to disclose.

This study was presented as a poster presentation at the APhA Annual Meeting, March 2018, Nashville, TN, and as a platform presentation at the Eastern States Conference, May 2018, Hershey, PA

\section{ACKNOWLEDGEMENTS}

The authors acknowledge Taylor Woodroof, PharmD, Clinical Applications Pharmacist, Johns Hopkins Home Care Group, for his contributions to electronic dashboard creation, metric analysis, and validation.

\section{REFERENCES}

1. Hagerman J, Freed S, Rice G. Specialty pharmacy: a unique and growing industry. Pharmacy Today. July 2013. Available at: https://www.pharmacytoday.org/article/S1042-0991(15)31266-4/pdf. Accessed June 9, 2020.

2. Vermeulen LC, Swarthout MD, Alexander GC, et al. ASHP Foundation forecast 2020: strategic planning advice for pharmacy departments in hospitals and health systems. Am J Health Syst Pharm. 2020;77(2):84-112.

3. IQVIA Institute. Medicine use and spending in the U.S.: a review of 2018 and outlook to 2023. May 9, 2019. Available at: https://www.iqvia.com/ insights/the-iqvia-institute/reports/medicine-use-and-spending-in-the-us-areview-of-2018-and-outlook-to-2023. Accessed June 9, 2020

4. American Society of Health-System Pharmacists Research and Education Foundation. Pharmacy forecast 2016-2020. December 2015. Available at: https://www.ashpfoundation.org/-/media/REF/Research/PDFs/2016_ PharmacyForecast_Report.ashx?la=en\&hash=D96B12332C34C044DlAD0E 5EBCF3C22B0D4A2D07. Accessed June 9, 2020.

5. Express Scripts. 2019 drug trend report. Available at: https://www. express-scripts.com/corporate/drug-trend-report\#2019-in-review. Accessed June 9, 2020.

6. American Society of Health-System Pharmacists. ASHP specialty pharmacy resource guide. Available at: https://www.ashp.org/-/media/assets/ pharmacy-practice/resource-centers/specialty-pharmacy/specialty-pharmacy-resource-guide.ashx?la=en\&hash=C38B8C24693D80CAE2377DC21FF0 BB613424CE3D. Accessed June 9, 2020

7. Allen SJ, Zellmer WA, Knoer SJ, et al. ASHP Foundation pharmacy forecast 2017: strategic planning advice for pharmacy departments in hospitals and health systems. Am J Health Syst Pharm. 2017;74(2):27-53.

8. Tang J, Bailey J, Chang C, et al. Effects of specialty pharmacy care on health outcomes in multiple sclerosis. Am Health Drug Benefits. 2016;9(8):420-29

9. Tkacz J, Brady BL, Meyer R, Lofland JH, Ruetsch C, Coelho-Prabhu N. An assessment of the AGA and CCFA quality indicators in a sample of patients diagnosed with inflammatory bowel disease. J Manag Care Spec Pharm. 2015;21(11):1064-76. Available at: https://www.jmcp.org/doi/10.18553/ jmcp.2015.21.11.1064.

10. Shah NB, Jolly JA, Horst, SN, et al. Development of quality measures for use of self-injectable biologic therapy in inflammatory bowel disease: an integrated specialty pharmacy initiative. Am J Health Syst Pharm. 2019;76(17):1296-304.

11. Pulvermacher A, Nelson C. Benefits of developing a collaborative, outcomes-based specialty pharmacy program. Am J Health Syst Pharm. 2016;73(11):839-43

12. URAC. Specialty pharmacy services accreditation. Available at: https:// www.urac.org/programs/specialty-pharmacy-services. Accessed June 9, 2020.

13. URAC. How pharmacy accreditation can boost patient outcomes. October 27, 2016. Available at: http://blog.urac.org/how-pharmacy-accreditation-can-boost-patient-outcomes. Accessed June 9, 2020. 
14. Therigy. Tips for managing the specialty pharmacy payer environment. April 17, 2017. Available at: http://therigy.com/tips-managing-specialtypharmacy-payer-environment. Accessed June 9, 2020.

15. Alrubaiy L, Hutchings HA, Williams JG. Assessing patient reported outcome measures: a practical guide for gastroenterologists. United European Gastroenterol J. 2014;2(6):463-70.

16. Cook KF, Victorson DE, Cella D, Schalet BD, Miller D. Creating meaningful cut-scores for Neuro-QOL measures of fatigue, physical functioning, and sleep disturbance using standard setting with patients and providers. Qual Life Res. 2015;24(3):575-89.

17. Alharbi FM. Update in vitamin D and multiple sclerosis. Neurosciences (Riyadh). 2015;20(4):329-35.

18. Jelsness-Jørgensen L, Moum B, Grimstad T, et al. Validity, reliability, and responsiveness of the brief pain inventory in inflammatory bowel disease. Can J Gastroenterol Hepatol. 2016;2016:5624261.
19. Robinson A, Kardos M, Kimball AB. Physician Global Assessment (PGA) and Psoriasis Area and Severity Index (PASI): why do both? A systematic analysis of randomized controlled trials of biologic agents for moderate to severe plaque psoriasis. J Am Acad Dermatol. 2012;66(3):369-75.

20. Lane S, Lozano-Ortega G, Wilson J, et al. Assessing severity in psoriasis: correlation of different measures (PASI, BSA, and IGA) in a Canadian realworld setting. Value Health. 2016;19(3):A122.

21. Clara I, Lix LM, Walker JR, et al. The Manitoba IBD Index: evidence for a new and simple indicator of IBD activity. Am J Gastroenterol. 2009;104(7):1754-63

22. Orr CK, Najm A, Young F, et al. The utility and limitations of CRP, ESR and DAS28-CRP in appraising disease activity in rheumatoid arthritis. Front Med (Lausanne). 2018;5:185. 